\title{
A wild common shrew (Sorex araneus) with an XXY sex chromosome constitution
}

\author{
J. B. Searle* \\ Department of Genetics, University of Aberdeen, Aberdeen AB9 2TN, U.K.
}

\begin{abstract}
Summary. An adult male common shrew with an XXY sex chromosome constitution was found in a natural population. The external appearance of the animal and size of the accessory glands were normal but the testes were as small as those of immature shrews. Histological preparations of the testis revealed seminiferous tubules containing only one type of cell, probably Sertoli cells, and interstitial cell hyperplasia.
\end{abstract}

\section{Introduction}

It is well-known that sex chromosome aneuploidy may promote abnormalities of sexual development in mammals. One such case of sex chromosome aneuploidy is the XXY condition (known as Klinefelter's syndrome in man) which generally results in a male phenotype with small testes lacking germ cells (Cattanach, 1974). In man, Klinefelter's syndrome is an important source of male infertility (e.g. Ábyholm \& Stray-Pedersen, 1981); the frequency of occurrence is 1 in every 1000 male babies (Hamerton, Canning, Ray \& Smith, 1975). The XXY condition has also been reported for a variety of domestic and laboratory mammals, specifically cat (Centerwall \& Benirschke, 1975), dog (Clough, Pyle, Hare, Kelly \& Patterson, 1970), pig (Breeuwsma, 1968), sheep (Bruère, Marshall \& Ward, 1969), bull (Scott \& Gregory, 1965), mouse (Cattanach, 1961), black rat (Yosida, 1979), Chinese hamster (Ivett, Tice \& Bender, 1978) and wood lemming (Gropp, Winking, Frank, Noack \& Fredga, 1976). To the author's knowledge, the XXY condition has previously been reported in only one wild mammal, an adult tamar wallaby (Macropus eugenii) (Sharman, Robinson, Walton \& Berger, 1970). The present paper describes an adult common shrew (Sorex araneus) with an XXY sex chromosome constitution, collected from the wild.

\section{Materials and Methods}

The XXY male was obtained during routine cytogenetic screening of a population of common shrews from Chalgrove, Oxfordshire, U.K., in May 1981. Direct air-dried chromosome preparations were made from bone marrow. Some preparations were stained conventionally with toluidine blue : resin (Breckon \& Evans, 1969), others were G-banded by a combined ASG-trypsin method (Searle, 1983). The genitalia were fixed in Bouin's fluid. Standard histological sections of 5 $\mu \mathrm{m}$ thickness were made from the left testis and stained with haematoxylin and eosin.

The genitalia of a male common shrew of normal karyotype trapped at the same site and time were treated identically for comparative purposes. This individual will be termed the 'control male'.

* Present address: Department of Agricultural Science, University of Oxford, Parks Road, Oxford OX1 3PF, U.K. 


\section{Results}

\section{Studies of the reproductive system}

In its external appearance and the size of accessory reproductive structures, the XXY male had a normal male phenotype. There were large lateral scent glands, clear inguinal bulges, a penis of normal appearance and no sign of nipples. The epididymis, vas deferens and prostate glands were identified from the descriptions of Brambell (1935) and were of a size and appearance similar to those observed in the control male.

However, the testes of the XXY male were minute in comparison to those of a normal adult male. The left testis of the XXY male weighed $2.0 \mathrm{mg}$ after fixation in Bouin's fluid, while that of the control male, treated similarly, weighed $155.4 \mathrm{mg}$. The testes of the XXY male were similar in size to those of immature common shrews (see Brambell, 1935). For example, the mean weight of a sample of 8 testes of immature animals collected in January and February 1981 and fixed in Bouin's fluid was $1.2 \mathrm{mg}$.

The histological sections revealed a notable difference in structure of the testes of the XXY and the control male (Pl. 1, Figs $1 \& 2$ ). The seminiferous tubules of the XXY male were smaller in diameter $(80 \mu \mathrm{m}$ average diameter, based on 10 tubules scored with a micrometer eyepiece), and less complex than those of the control male $(190 \mu \mathrm{m}$ average diameter), which show normal spermatogenic activity. Only one type of cell nucleus could be distinguished clearly within the tubules of the XXY male; these nuclei were located near the basement membrane. As there appear to have been no thorough studies of the cell types in seminiferous tubules of shrews or other insectivores (Roosen-Runge, 1977), it is not possible to identify the cell nuclei within the tubules of the XXY male with certainty. However, on the basis of the size, light staining and irregular outline of these nuclei, they resembled what are believed to be the nuclei of Sertoli cells in the control male.

There were also considerable differences in interstitial tissue between the control and XXY males. In the control male there were only small groups of Leydig cells between the seminiferous tubules (P1. 1, Fig. 2), but in the XXY male there was a substantial, continuous matrix of this cell type (P1. 1, Fig. 1) such that most of the testis volume would have consisted of interstitial tissue.

\section{Karyotypic analysis}

Six G-banded spreads of bone marrow cells from the XXY male were suitable for analysis. The karyotype shown in Pl. 1, Fig. 3 was prepared from one of these spreads. In all the G-banded spreads two $\mathrm{X}$ chromosomes and a $\mathrm{Y}$ chromosome were observed. The animal was collected from an area of polymorphism for Robertsonian translocations (Searle, 1983) and the karyotype indicated translocation heterozygosity for three polymorphic arm combinations, i.e. kq, no and pr (see Halkka, Halkka, Skarén \& Söderlund (1974) for the normal karyotype and details of nomenclature).

The chromosome preparations provided no indication of sex chromosome mosaicism. Of 50 conventionally stained spreads scored for karyotype (Table 1), 43 had the chromosome composition expected from the G-band karyotype, i.e. with a chromosome number of 24 and a chromosome arm number of 41 (see Pl. 1, Fig. 3). The chromosome counts of 6 other spreads can be accounted for by

\section{PLATE 1}

Fig. 1. Histological section of the left testis of the XXY common shrew. Note the simple seminiferous tubules and the interstitial cell hyperplasia. Scale bar represents $100 \mu \mathrm{m}$.

Fig. 2. Histological section of the left testis of a control shrew, showing normal spermatogenesis, for comparison with Fig. 1.

Fig. 3. G-band karyotype of the XXY common shrew. Chromosome arms are labelled according to the standard nomenclature (Halkka et al., 1974). 
PLATE 1

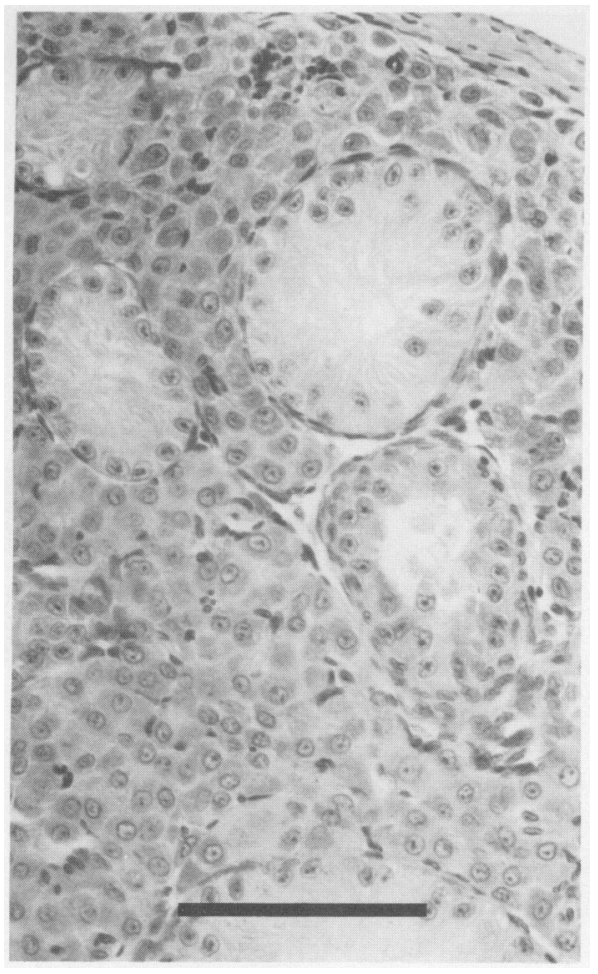

Fig. 1

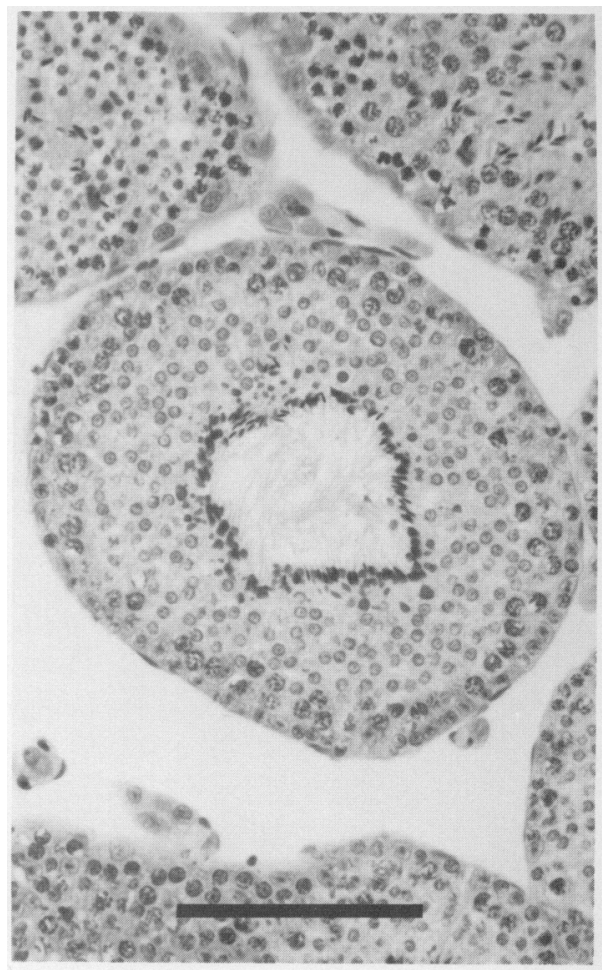

Fig. 2

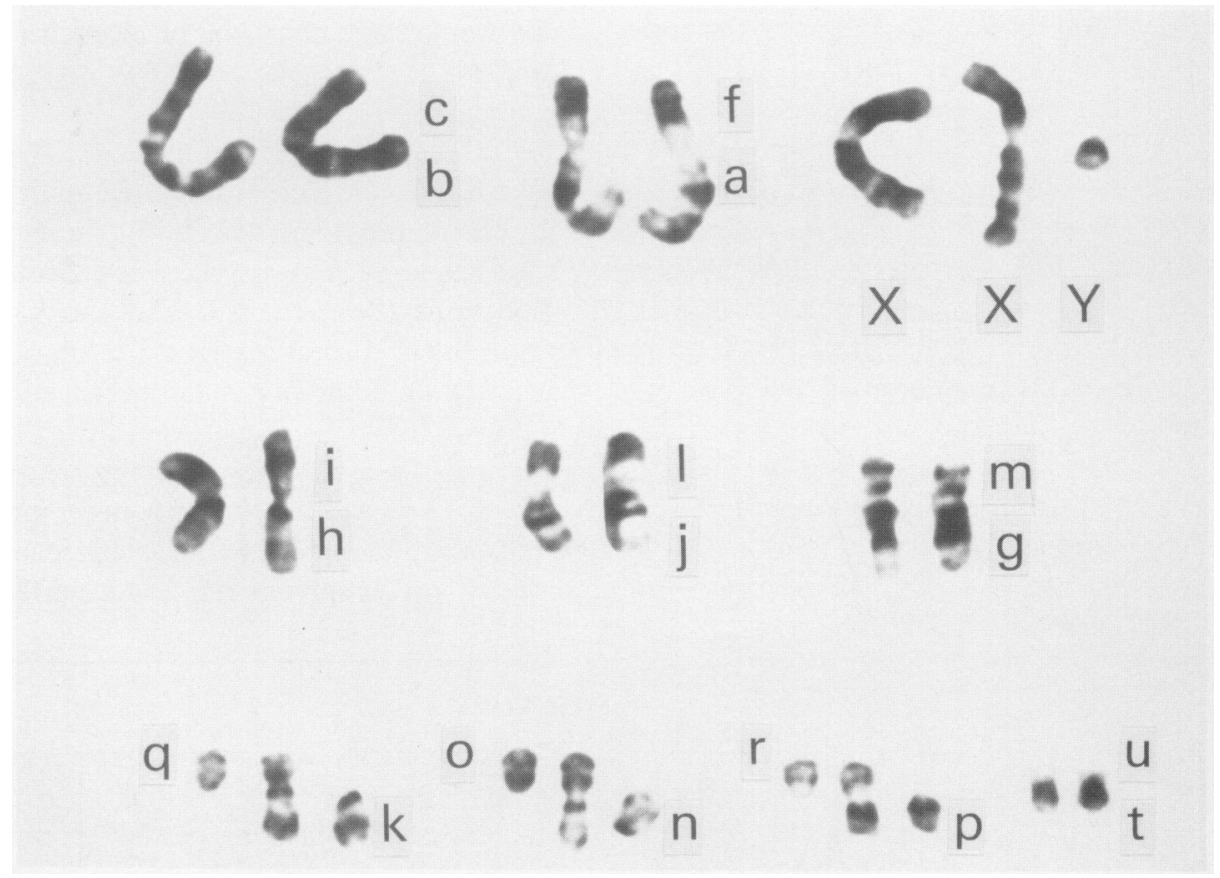

Fig. 3

(Facing p. 354) 
Table 1. The chromosome constitution of 50 conventionally stained spreads of bone marrow cells from the XXY shrew

\begin{tabular}{lrrrr}
\hline No. of chromosomes & 25 & 24 & 23 & 23 \\
No. of chromosome arms & 42 & 41 & 40 & 39 \\
No. of spreads scored & 1 & 43 & 3 & 3 \\
\hline
\end{tabular}

artefactual loss of chromosomes during preparation. In a further spread of one cell there was an extra chromosome; this cell may have been the product of mitotic non-disjunction.

\section{Discussion}

The phenotypic manifestation of the XXY condition in the common shrew accords well with that found in other mammals. As in other species, there is a male phenotype in terms of external appearance and accessory reproductive structures, while the presence of small testes appears to be general (Cattanach, 1974).

The testes of the XXY shrew were very different histologically from the testes of immature common shrews as described by Saure, Heikura, Pelttari \& Talman (1972), although they were of similar size. In immature shrews, the testes are predominantly occupied by seminiferous tubules containing spermatogonia and precursors of Sertoli cells, and the Leydig cells form small groups between tubules as in normal adult males (see Pl. 1, Fig. 2). In contrast, most of the space within the testis of the XXY male was occupied by interstitial tissue; seminiferous tubules occurred at a low density and appeared to contain only Sertoli cells (see Pl. 1, Fig. 1). These histological differences suggest that testicular development in the XXY male has not been arrested at a stage equivalent to that of immature shrews.

The histological picture of the testis of the XXY common shrew resembles that observed in other adult mammals with the XXY condition. In all animals for which the testes have been examined histologically (man: Ferguson-Smith, Lennox, Stewart \& Mack, 1960; dog: Clough et al., 1970; pig: Hancock \& Daker, 1981 ; sheep: Bruère et al., 1969; cat: Centerwall \& Benirschke, 1975; mouse: Cattanach, 1974; wood lemming: Gropp et al., 1976; tamar wallaby: Sharman et al., 1970), simplified tubules lined with Sertoli cells and/or spermatogonia have been reported. Interstitial cell hyperplasia was noted as a characteristic of the XXY condition in man, cat, sheep, mouse and wood lemming.

I thank the Histology Section of the M.R.C. Radiobiology Unit, Harwell for making the sections illustrated in this paper, Dr J. R. Clarke for discussions and Dr A. E. Douglas and Dr J. R. Clarke for reading earlier drafts of this manuscript. This work was conducted during a Ph.D. study supervised by Professor F. W. Robertson and supported by S.E.R.C.

\section{References}

Ảbyholm, T. \& Stray-Pedersen, S. (1981) Hypospermiogenesis and chromosome abberations. A clinical study of azoospermic and oligozoospermic men with normal and abnormal karyotype. Int. J. Androl. 4, $546-558$.

Brambell, F.W.R. (1935) Reproduction in the common shrew (Sorex araneus Linnaeus). II. Seasonal changes in the reproductive organs of the male. Phil. Trans. $R$. Soc. B 225, 51-62.

Breckon, G. \& Evans, E.P. (1969) A combined toluidine blue stain and mounting medium. In Comparative Mammalian Cytogenetics, pp. 465-466. Ed. K. Benirschke. Springer-Verlag, Berlin.
Breeuwsma, A.J. (1968) A case of XXY sex chromosome constitution in an intersex pig. J. Reprod. Fert. 16, 119-120.

Bruère, A.N., Marshall, R.B. \& Ward, D.P.J. (1969) Testicular hypoplasia and XXY sex chromosome complement in two rams: the ovine counterpart of Klinefelter's syndrome in man. J. Reprod. Fert. 19, 103-108.

Cattanach, B.M. (1961) XXY mice. Genet. Res. 2, 156158.

Cattanach, B.M. (1974) Genetic disorders of sex determination in mice and other mammals. In 4th International Conference on Birth Defects, pp. 129-141. Eds 
A. G. Motulsky \& W. Lentz. Excerpta Medica, Amsterdam.

Centerwall, W.R. \& Benirschke, K. (1975) An animal model for the XXY Klinefelter's syndrome in man: tortoiseshell and calico male cats. Am. J. vet. Res. 36, 1275-1280.

Clough, E., Pyle, R.L., Hare, W.C.D., Kelly, D.F. \& Patterson, D.F. (1970) An XXY sex-chromosome constitution in a dog with testicular hypoplasia and congenital heart disease. Cytogenetics 9, 71-77.

Ferguson-Smith, M.A., Lennox, B., Stewart, J.S.S. \& Mack, W.S. (1960) Klinefelter's syndrome. Mem. Soc. Endocr. 7, 173-181.

Gropp, A., Winking, H., Frank, F., Noack, G. \& Fredga, K. (1976) Sex-chromosome abberations in wood lemmings (Myopus schisticolor). Cytogenet. \& Cell Genet. 17, 343-358.

Halkka, L., Halkka, O., Skarén, U. \& Söderlund, V. (1974) Chromosome banding pattern in a polymorphic population of Sorex araneus from northeastern Finland. Hereditas 76, 305-314.

Hamerton, J.L., Canning, N., Ray, M. \& Smith, S. (1975) A cytogenetic survey of 14,069 newborn infants. I. Incidence of chromosome abnormalities. Clin. Genet. 8, 223-243.

Hancock, J.L. \& Daker, M.G. (1981) Testicular hypoplasia in a boar with abnormal sex chromosome constitution (39 XXY). J. Reprod. Fert. 61, 395-397.
Ivett, J.L., Tice, R.R. \& Bender, M.A. (1978) Y two X's? An XXY genotype in Chinese hamster, $C$. griseus. J. Hered. 69, 128-129.

Roosen-Runge, E.C. (1977) The Process of Spermatogenesis in Animals. Cambridge University Press, Cambridge.

Saure, L., Heikura, K., Pelttari, A. \& Talman, T. (1972) The functioning of the testes in the common shrew (Sorex araneus L.) in Northern Finland. Aquilo, Ser. Zool. 13, 81-86.

Scott, C.D. \& Gregory, P.W. (1965) An XXY trisomic in an intersex of Bos taurus. Genetics, Princeton 52, 473474.

Searle, J.B. (1983) Robertsonian chromosomal variation in the common shrew Sorex araneus $L$. Ph.D. thesis, University of Aberdeen.

Sharman, G.B., Robinson, E.S., Walton, S.M. \& Berger, P.J. (1970) Sex chromosomes and reproductive anatomy of some intersexual marsupials. $J$. Reprod. Fert. 21, 57-68.

Yosida, T.H. (1979) Sex chromosome anomalies in $F_{2}$ hybrids between Oceanian and Ceylonese type black rats. Jap. J. Genet. 54, 27-34.

Received 30 July 1983 